\title{
Freshwater components and transports in the Fram Strait - recent observations and changes since the late 1990s
}

\author{
B. Rabe ${ }^{1}$, U. Schauer ${ }^{1}$, A. Mackensen ${ }^{1}$, M. Karcher ${ }^{1}$, E. Hansen ${ }^{2}$, and A. Beszczynska-Möller ${ }^{1}$ \\ ${ }^{1}$ Alfred Wegener Institute for Polar and Marine Research, Bremerhaven, Germany \\ ${ }^{2}$ Norwegian Polar Institute, Tromsoe, Norway \\ Received: 10 March 2009 - Published in Ocean Sci. Discuss.: 20 March 2009 \\ Revised: 23 June 2009 - Accepted: 26 Jun 2009 - Published: 7 July 2009
}

\begin{abstract}
We present the late summer distribution and transports of freshwater components in the upper western part of the Fram Strait during 1998, 2004 and 2005. Hydrographic data and and water $\delta^{18} \mathrm{O}$ values are analyzed to distinguish Atlantic Water, ice melt (SIM) and freshwater removal from ice formation (IFB), and Meteoric Water (precipitation and riverine sources; MW). Concentrations of these water masses are combined with volume transport estimates from an inverse model. The average liquid freshwater transport relative to a reference salinity of 34.92 , was $2500 \mathrm{~km}^{3} / \mathrm{yr}$ or $80 \mathrm{mSv}$ southward, which is at the upper end of values reported in the literature. Our results indicate that not only the region of the continental slope but also parts of the East Greenland Shelf are important for freshwater transports.

We estimate the average transports of of MW and IFB to be between 130 to $160 \mathrm{mSv}$ ( 4100 to $5000 \mathrm{~km}^{3} / \mathrm{yr}$ ) and 60 to $90 \mathrm{mSv}$ (1900 to $2800 \mathrm{~km}^{3} / \mathrm{yr}$ ) southward, respectively. The southward transport of MW was higher in 2005 than in 1998, but was compensated by a higher IFB transport. These differences in transports were associated with stronger southward velocities and the absence of northward velocities over the continental slope and the eastern East Greenland Shelf in 2005. A simulation using the North Atlantic-Arctic Ocean Sea Ice Model (NAOSIM) shows that the high transport of MW in the Fram Strait in 2005 is in agreement with the temporary storage of river water on the Siberian shelf in the mid1990s, which reached the north of Greenland in 2003. Our results indicate that the accumulation of increased amounts of river water on the shelves is associated with enhanced ice formation.
\end{abstract}

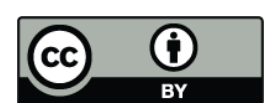

Correspondence to: $\mathrm{B}$. Rabe (benjamin.rabe@awi.de)

\section{Introduction}

The Greenland-Iceland-Norwegian Seas and the Arctic Ocean input around $160 \mathrm{mSv}$ of freshwater $(\mathrm{FW})$ in liquid and solid form into the North Atlantic (Aagaard and Carmack, 1989) $)^{1}$, a large part of which is exported from the Arctic through the Fram Strait. Model studies have shown that variability of this FW input changes conditions in the regions of deep water formation in the North Atlantic, which can influence the large-scale ocean circulation (Häkkinen, 1999; Haak et al., 2003) and potentially climate. Not only the Meridional Overturning Circulation (MOC), but also the horizontal gyres (Brauch and Gerdes, 2005) may be affected. However, the processes associated with storage and export of FW in Arctic Ocean and the Nordic Seas are not yet well understood (e.g. Häkkinen and Proshutinsky, 2004). We refer the reader to Dickson et al. (2007) for a recent review of observational and modeling studies related to the Arctic FW budget.

The importance of the Fram Strait for FW transports has been shown in several modeling studies (e.g. Köberle and Gerdes, 2007; Gerdes et al., 2008). Observational estimates of the volume transport through the Fram Strait from moored instruments exist since the 1980s (e.g. Foldvik et al., 1988), but they are limited to discrete locations and cover only the eastern and central part of the Fram Strait up to about $8^{\circ} \mathrm{W}$ (Holfort et al., 2008; Schauer et al., 2004; Fahrbach et al., 2001). A recent modeling study suggests that a significant portion of the liquid FW transport occurs on the East

\footnotetext{
${ }^{1}$ The freshwater transports were calculated relative to salinities of 34.8 for the Canadian Archipelago and 34.93 for the GreenlandIceland-Scotland ridge system. The sum represents the freshwater export from the Greenland-Iceland-Norwegian Seas and the Arctic Ocean into the North Atlantic.
}

Published by Copernicus Publications on behalf of the European Geosciences Union. 
Greenland Shelf west of $8^{\circ} \mathrm{W}$ (Gerdes et al., 2008). Observations covering also the eastern shelf exist only in the form of shipboard surveys; for example, the evolution of the liquid FW transport along the East Greenland Current (EGC) has recently been described by Nilsson et al. (2008) using current profile measurements during late winter, 2002.

The FW is transported through the Fram Strait as an admixture of the upper ocean inflows into the Arctic Ocean, which are Atlantic Water (AW), Pacific Water (PW) and Meteoric Waters (MW), the latter denoting river inflow and precipitation. Some of the AW entering from the Greenland-Iceland-Norwegian Sea through the eastern Fram Strait and the Barents Sea is modified through cooling, freezing/melting and mixing with MW to become part of the lower halocline, overlying the warm AW core. Two distinct circulation branches for the lower halocline have been identified by their temperature and salinity characteristics to originate in the Fram Strait and the Barents Sea (Rudels et al., 2004). On the other hand, the circulation and temperature and salinity properties of the upper halocline are less clear and strongly influenced by processes at the ocean surface throughout the whole Arctic Ocean.

To discriminate between the origins of upper ocean waters in the Arctic, not only temperature and salinity but also nutrients (Falck et al., 2005), dissolved Barium (Taylor et al., 2003) and alkalinity (Jones et al., 2008b) have been used. Fractions of AW, MW and ice melt have been determined using measurements of salinity and the oxygen isotopes ${ }^{18} \mathrm{O}$ and ${ }^{16} \mathrm{O}$, represented by the quantity $\delta^{18} \mathrm{O}$ (Jones et al., 2008a; Yamamoto-Kawai et al., 2008; Ekwurzel et al., 2001; Bauch et al., 1995; Schlosser et al., 1994). MW, from precipitation and input from North American and Eurasian rivers, is depleted in ${ }^{18} \mathrm{O}$, and hence has low $\delta^{18} \mathrm{O}$, due to low atmospheric temperatures at high latitudes and repeated precipitation and evaporation (Schlosser et al., 2000). AW, on the other hand, has a relatively high salinity and $\delta^{18} \mathrm{O}$ values close to zero. Whereas Sea Ice Melt Water (SIM) is associated with a slightly higher $\delta^{18} \mathrm{O}$ than that of the water the ice was formed from, ice formation leads to an increase in salinity and lowering of $\delta^{18} \mathrm{O}$ in the surrounding water (Melling and Moore, 1995); such water will be termed Ice-Formation brine Water (IFB) for the remainder of this work. Its volume is equivalent to the amount of liquid water contained in formed ice; however, the presence of IFB in the Fram Strait does not imply that the ice is also present there. Rather, the southward transport of IFB through the Fram Strait represents a removal of brine, formed due to ice formation, from the Arctic Ocean and hence the southward transport of a freshwater deficit. PW has slightly lower salinity and $\delta^{18} \mathrm{O}$ than $\mathrm{AW}$ and cannot be distinguished without the use of other tracers, such as nutrients. In the Fram Strait, Meredith et al. (2001) used $\delta^{18} \mathrm{O}$ and salinity from hydrographic surveys to study the content of MW and SIM/IFB. Furthermore, the evolution of $\delta^{18} \mathrm{O}$ and fractions of MW, SIM and AW along the whole length of the EGC have been analyzed by Dodd (2008) and Dodd et al. (2009). They found that glacial melt-water runoff from Greenland shows properties similar to MW.

In the early 1990s, the near-surface circulation in the Arctic changed. Steele et al. (2004) compared hydrographic measurements with a summer climatology of the 40 years prior to 1990 and found an anti-clockwise shift of the front separating near-surface waters of Atlantic and Pacific origin. This in turn allowed PW to reach the Fram Strait. The shift of the front was caused by a weakening of the anti-cyclonic Beaufort Gyre associated with a positive Arctic Oscillation index and a dominant cyclonic circulation in the atmosphere. Furthermore, the Eurasian river water left the Siberian shelves further eastward than before and did not directly flow across the central Arctic toward the Fram Strait and the Canadian Archipelago (Schlosser et al., 2002; Guay et al., 2001). Recently (post-1990s) oceanic conditions in the Arctic, associated with a negative Arctic Oscillation, changed back to pre-1990s conditions (Morrison et al., 2006). Therefore, the amount of river water was again increasing in the Eurasian part of the Arctic Ocean (Jones et al., 2008a; Anderson et al., 2004) and PW no longer appeared to reach the Fram Strait, as seen in 2004 and 2005 hydrographic and nutrient measurements (Falck et al., 2005, personal communication).

In this work we present an analysis of the water mass components of FW and their transports in the upper $400 \mathrm{~m}$ of the Fram Strait from three shipboard surveys and mooring observations from the late summer periods of 1998, 2004 and 2005. Time series of the moorings show that the seasonal amplitude of the FW transport is of similar magnitude as the annual mean (de Steur et al., 2009). However, the moorings capture only the flow up to the easternmost part of the shelf whereas the surveys allow to extend the analysis further onto the East Greenland Shelf. The hydrographic and mooring data from 1998 have been analyzed previously in Meredith et al. (2001). Here, the velocity data from moored current meters and a vessel-mounted Acoustic Doppler Current Profiler (ADCP), and hydrographic sections are used to derive transport estimates across a meridional section along about $79^{\circ} \mathrm{N}$ using the Finite Element Method Section model (FEMSECT; Losch et al., 2005). Fractions of MW, SIM and $\mathrm{AW}$ are derived from salinity and $\delta^{18} \mathrm{O}$ measurements using the method by Bauch et al. (1995). The hydrography and water mass content are analyzed in Sect. 3 and the velocity and transports are presented and discussed in Sect. 4. Our shipboard observations necessarily represent snapshots of the summer conditions in the western Fram Strait

Bearing this in mind, our observational results will be discussed in Sect. 5 in the light of changes known to have occurred throughout the Arctic between 1990 and 2005. We further compare our observational results to a simulation of riverine water distribution and variability using the North Atlantic-Arctic Ocean Sea Ice Model (NAOSIM, Karcher et al., 2006, 2005). 


\section{Methods}

\subsection{Hydrography and $\delta^{18} O$ samples}

Profiles of temperature and salinity were obtained during ARK XIV/2 (1998), ARK XX/2 (2004) and ARK XXI/1b (2005) from the RV Polarstern (Fig. 1b). The hydrographic surveys and instrumentation are described in Fahrbach et al. (2007). Whenever we refer to our results from 1998, 2004 and 2005 throughout this work, it implies that data from July, August and September have been used. Throughout this paper, potential temperature relative to surface pressure is denoted as $\theta$ and potential density by $\sigma_{\theta}$ (departures from $1000 \mathrm{~kg} / \mathrm{m}^{3}$ ). Salinity will sometimes be referred to by the letter "S".

For determination of the ${ }^{18} \mathrm{O} /{ }^{16} \mathrm{O}$ ratio in water (see also Mackensen, 2001), we collected $100 \mathrm{ml}$ from 101 Niskin sampling bottles at several stations (Fig. 1a). All water samples were drawn into glass vials, sealed with wax under $4^{\circ} \mathrm{C}$ air temperature, and kept cool until further treatment on shore. In the laboratory $7 \mathrm{ml}$ of water were equilibrated in $13 \mathrm{ml}$ headspace with $\mathrm{CO}_{2}$ gas by using an automated Finnigan equilibration device. Isotope equilibrium in the $\mathrm{O}_{2}-\mathrm{H}_{2} \mathrm{O}$ system was attained by shaking for $430 \mathrm{~min}$ at $20^{\circ} \mathrm{C}$. The equilibrated gases were purified and transferred to an on-line connected Finnigan MAT Delta-S mass spectrometer. Isotope preparation and measurements were calibrated against Vienna Standard Mean Ocean Water (VSMOW) and Vienna Standard Light Antarctic Precipitation (VSLAP) standard waters. At least two replicates (including preparation and measurement) were run for each oxygen isotope determination. Results are reported in $\delta$-notation $\left(\delta^{18} \mathrm{O}\right)$ relative to the VSMOW-scale with an external reproducibility of $0.03 \%$.

Although $\delta^{18} \mathrm{O}$ samples were taken for many of the CTD profiles in 2005, in the region of the East Greenland Front (EGF) only two $\delta^{18} \mathrm{O}$ samples were taken (Fig. 1). However, $\delta^{18} \mathrm{O}$ samples in the 2004 section cover this region. A piecewise regression of the 2004 data (Fig. 2c) shows that the salinity $<32.7(>32.7)$ accounts for $90 \%(\% 47)$ of the $\delta^{18} \mathrm{O}$ variability. Using this regression, we can reconstruct the gap in the $\delta^{18} \mathrm{O}$ data in 2005 using salinity from CTD casts, interpolated to $10 \mathrm{~m}$ depth levels. The regression ignores the direct mixing between saline Atlantic water and low-salinity, low- $\delta^{18} \mathrm{O}$ water. To test the impact of ignoring those data points on the regression, we calculate $\delta^{18} \mathrm{O}$ from the 2004 salinity from CTD casts and compare it to the actual measurements of $\delta^{18} \mathrm{O}$. The reconstructed $\delta^{18} \mathrm{O}$ (not shown) preserves the overall pattern of the actual measurements while having weaker maxima, in particular around the EGF. This is due to the non-linear nature of the salinity vs. $\delta^{18} \mathrm{O}$ relationship for high salinities, where the linear regression underestimates $\delta^{18} \mathrm{O}$ for a given salinity. Therefore, we find that the water mass transports from reconstructed values overestimate those from measured data, in particular over the conti-
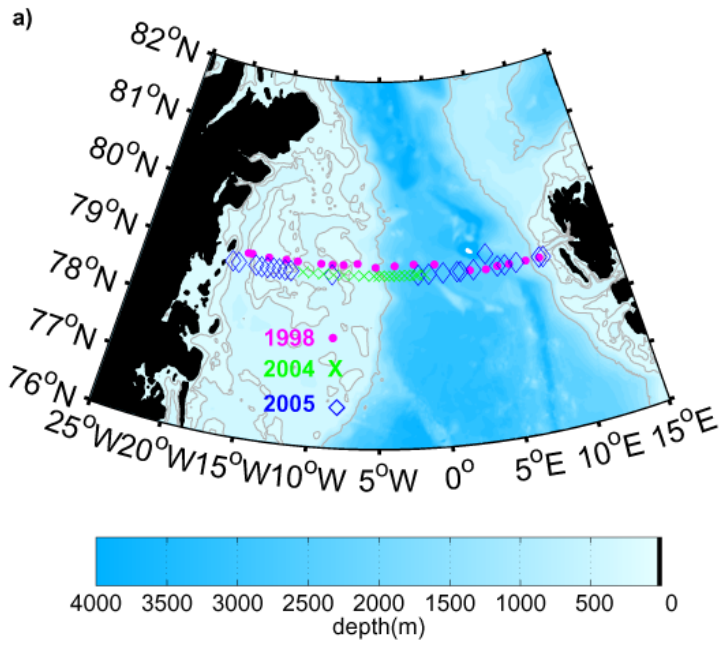

b)

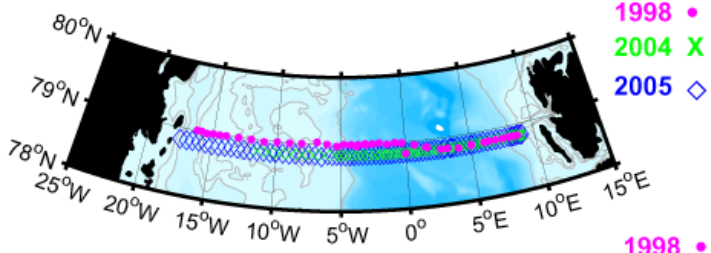

c)

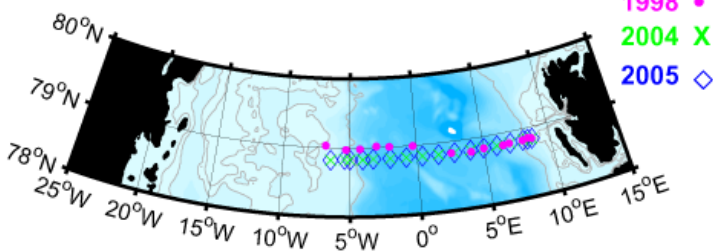

Fig. 1. Locations of the $\delta^{18} \mathrm{O}$ sample stations (a), the temperature and salinity profiles (b) and the moorings (c): Polarstern cruises ARK XIV/2a (1998; magenta dots), ARK XX/2 (2004, green crosses) and ARK IXX/1b (2005, blue diamonds). Color shading represents the seafloor topography of the survey region from the IBCAO database (Jakobsson et al., 2008). Gray contour lines denote the 100, 200 and $1000 \mathrm{~m}$ isobaths.

nental slope. Differences for the transports of MW cumulate to $20 \%$ and for SIM/IFB to $28 \%$. Errors from all sources are discussed in Appendix A.

\subsection{Velocity measurements}

We use meridional velocity data along about $79^{\circ} \mathrm{N}$ from two different sources:

I Point measurements by Aanderaa RCM and FSI current meters and profiles from three near-surface upward looking ADCP. The instruments were moored along the stations of the hydrographic survey (see Fig. 1).

II Continuous underway velocity profiles obtained with a vessel-mounted ADCP during the three hydrographic surveys in the Fram Strait in the summer periods of 1998, 2004 and 2005. 
Velocity from moored instruments was averaged for each month where the majority of the hydrographic survey took place. In cases where recovery and deployment of the instruments lead to large gaps in the mooring records, an adjacent month was chosen instead. The 2-min ensemble profiles of the vessel-mounted ADCP were extracted in $10 \mathrm{~m}$ depth intervals and detided using predictions from the barotropic Arctic Ocean Tidal Inverse Model (AOTIM-5; Padman and Erofeeva, 2004). This model is only an approximation to the real ocean tides, that, in addition, have a baroclinic component dependent on the bathymetry and ocean stratification. However, the discrepancy between tides in the model and those measured by current meters moored along $79^{\circ} \mathrm{N}$ in the Fram Strait has been found to be about $0.01 \mathrm{~m} / \mathrm{s}$ in the deeper parts of the section and less in the upper layers, where FW is observed (Behrendt, 2008). The detided underway ADCP profiles were median-averaged to hourly values; standard deviations for the data within each hour were generally below $0.1 \mathrm{~m} / \mathrm{s}$.

\subsection{Inverse analysis}

To obtain a physically consistent estimate of meridional velocity and transport from our data, we use an inverse analysis model, FEMSECT (Losch et al., 2005). The model uses the baroclinic thermal wind equation as its physical basis, additionally allowing a non-zero barotropic velocity. The initial model fields consist of our hydrographic data, from which geostrophic velocity is calculated, setting the barotropic velocity to zero. These initial fields are subsequently modified in an iterative procedure, where the data constraints are used to minimize the model-data differences. The model is constrained by observations of temperature, salinity and velocity. It recalculates each of these quantities on the model grid for each iteration, minimizing an objective function that represents the model-data differences in a least squares sense. The velocity measurements are linearly interpolated onto the measurement grid of the hydrography before being used as a data constraint by FEMSECT. For further details we refer the reader to Losch et al. (2005). The final optimized model solution not only gives velocity and transport estimates but also an error estimate dependent on the modeldata differences of the final solution and the observational error estimates. The latter include both the instrumental error and the time variability of each measured parameter during the survey. We choose the same a-priori errors as Losch et al. (2005): $0.01 \mathrm{~m} / \mathrm{s}$ for the monthly averaged current meter velocity, $1^{\circ} \mathrm{C}$ for temperature and 0.1 for salinity. For the hourly averaged underway ADCP profiles, we assume the non-tidal variability of velocity during the ship surveys to be $0.10 \mathrm{~m} / \mathrm{s}$; for comparison, Nilsson et al. (2008) states temporal (non-tidal) flow variations, as captured by their Lowered ADCP survey along $79^{\circ} \mathrm{N}$, of the order of $0.10 \mathrm{~m} / \mathrm{s}$.

\section{Hydrography and FW components}

\subsection{Temperature, salinity and $\delta^{18} \mathbf{O}$}

The upper $400 \mathrm{~m}$ of all our three hydrographic sections near $79^{\circ} \mathrm{N}$ showed a distinct front around the zero isotherm in the vicinity of the shelf edge in the west, the East Greenland Front (EGF; Fig. 3b). East of the EGF we found warmer and relatively salty waters of mainly Atlantic origin (e.g. Schauer et al., 2004; Schlichtholz and Houssais, 2001). To the west of this front we observed waters much fresher than in the east, which have been termed Polar Surface Waters (PSW), defined by salinities below 34.4 (Schlichtholz and Houssais, 2001). Most of the PSW have negative $\delta^{18} \mathrm{O}$, whereas the waters of Atlantic origin are characterized by values between 0 and $0.5 \%$ (Fig. 3a). On the shelf, in the deep channel around $17^{\circ} \mathrm{W}, \delta^{18} \mathrm{O}$ above $0 \%$ confirm the Atlantic origin, as was suggested by Budéus et al. (1997) and Bourke et al. (1987). West of the EGF the minima of both salinity and $\delta^{18} \mathrm{O}$ are near the surface, whereas the lowest temperatures lie between 50 and $100 \mathrm{~m}$ (not shown). The low temperatures are closest to freezing at salinities of 33 and 34.3 (Fig. 2a). At salinities above 34.3 the temperature increases, which forms a sharp bend in the $\theta$ vs. salinity diagram (Fig. 2a). This bend has been associated with Lower Halocline Water (LHW) that is formed by freezing, winter convection and melting in the Fram Strait branch (Rudels et al., 2004). Waters of similar salinity but higher temperature are associated with the Barents Sea branch of the lower halocline. The LHW has $\delta^{18} \mathrm{O}$ values close to zero, confirming LHW to be primarily originating in AW, as suggested by Rudels et al. (2004).

The distribution of $\delta^{18} \mathrm{O}$ vs. salinity (Fig. 2b) enables us to further distinguish waters with low salinity, overlying the LHW: Most of such waters, with salinities below $~ 34.3$, depart from the direct mixing line of AW and MW; we assume that MW has a value of $\delta^{18} O \sim-18 \%$, based on Ekwurzel et al. (2001).

Few values lie to the left of this mixing line and are mostly found at depths shallower than $25 \mathrm{~m}$ in our observations (Fig. 3). Such properties are generally associated with SIM (e.g. Ekwurzel et al., 2001; Bauch et al., 1995). To the right of the mixing line, there is a distinct bend around $\left\{S=33, \delta^{18} \mathrm{O}=-2.5 \%\right.$. This suggests a mixing triangle between the water at this bend, which we will refer to as Fram Strait Upper Halocline Water (FUHW), and the corners marked in Fig. 2a. These corners are located around $\left\{S=34.3, \delta^{18} \mathrm{O}=0\right\}$ (LHW) and $\left\{S=30, \delta^{18} \mathrm{O}=-2.6 \%\right.$. As FUHW lies to the right of the AW-MW mixing line, it is likely to contain IFB from winter ice formation, which is further supported by the near-freezing temperatures we observe (Fig. 2a).

Similarly shaped departures from the MW-AW mixing line have been observed in other parts of the Arctic: North of the Fram Strait and across the central Arctic toward the Bering Strait, Ekwurzel et al. (2001) observed a bend at about 

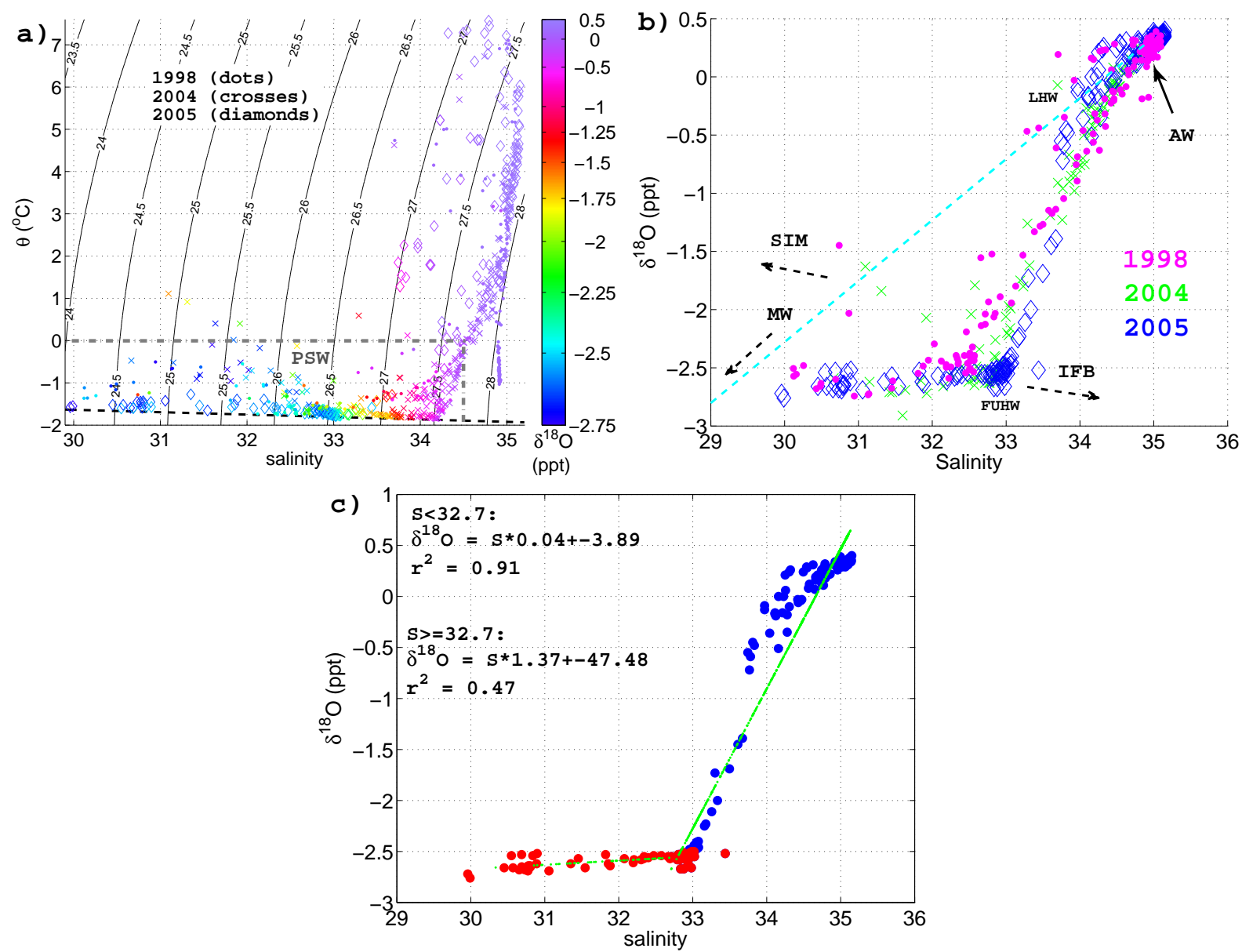

Fig. 2. (a) Potential temperature, $\theta$, vs. salinity and $\delta_{18} \mathrm{O}$ in color, with contours of potential density, $\sigma_{\theta}\left(\mathrm{kg} / \mathrm{m}^{3}\right)$, from our observations in 1998, 2004 and 2005. The dashed line shows the freezing temperature. (b) Salinity vs. $\delta^{18} \mathrm{O}$, where direct mixing between the MW and AW end-members would be along the cyan dashed line. The dashed arrows show the direction of $S / \delta^{18} \mathrm{O}$ development during ice formation (IFB) and melting (SIM). For other abbreviations see text. (c) Piecewise linear regression of salinity and $\delta^{18} \mathrm{O}$ in a longitude band of 1.5 to $12.5^{\circ} \mathrm{W}$ for pressures below $310 \mathrm{dbar}$ (see text for details). The red and green colors represent the data leading to each of the two regressions. The reconstruction of the $\delta^{18} \mathrm{O}$ values from salinity based on these regressions are represented by the green dots. Also shown are the regression equations and the square of the correlation coefficients $\left(r^{2}\right)$.

the same salinity $(\sim 33)$ but at higher $\delta^{18} \mathrm{O}$ values $(-2$ to $\sim-1.5 \%$ o). They found water with such properties to be a mixture of IFB, MW and PW and termed it Upper Halocline Water. In the continental shelf areas of the Laptev and Kara Seas, Bauch et al. (2005) observed a bend around $\left\{S=30, \delta^{18} \mathrm{O}=-4 \%\right.$ o $\}$ during the summer periods of 1999 to 2001. Since ice on the Eurasian shelves is formed from water that is a mixture of AW and MW, Bauch et al. (2005) also associated this bend with winter ice formation, i.e. IFB. Our FUHW has a higher salinity and $\delta^{18} \mathrm{O}$ than the "bend water" described by Bauch et al. (2005). However, FUHW does not lie on a direct mixing line between their water and LHW. There are two possibilities how FUHW may have been formed: First, it could be generated directly through ice formation from other Arctic shelf water than the Bauch et al. (2005) "bend water" was formed from. If originating from the AW-MW mixing line, fractionation would require a source water mass of $\left\{S=30.5, \delta^{18} \mathrm{O}=-2.3 \%\right.$ o $\}$ for our FUHW value in the Fram Strait. A second possibility is indicated by the analysis by Bauch et al. (2005), who state that their bend water and waters with salinity lower than 30 do not follow the same pathways during export from the shelves into the deep basins. Hence, it is conceivable that their bend water mixes with LHW after leaving the shelves, and that the mixture subsequently encounters water with similar $\delta^{18} \mathrm{O}$, lying on the AW-MW mixing line. However, without further information, such as data from additional tracers, we cannot determine if one or both of the two scenarios are true. 

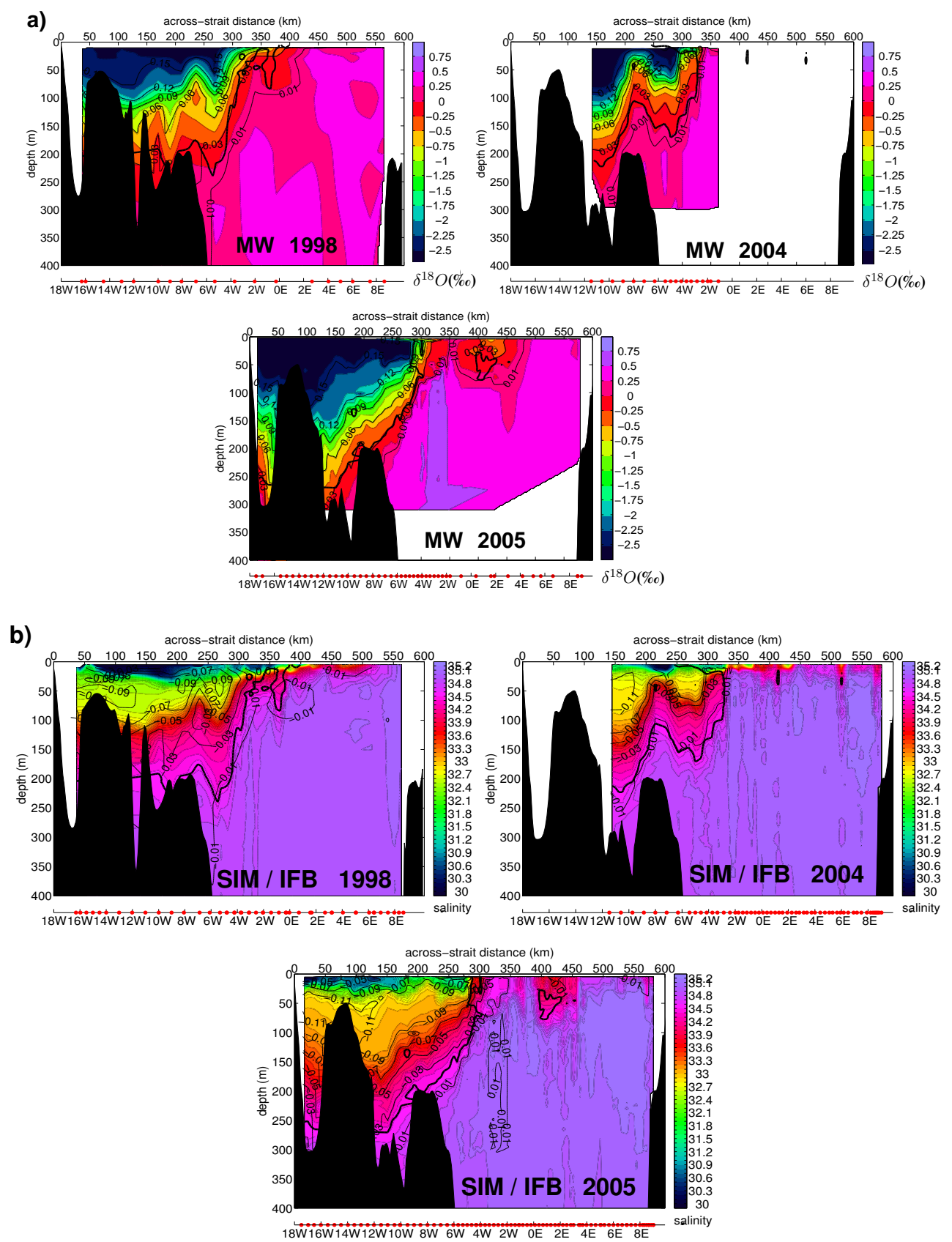

Fig. 3. Distribution of $\delta^{18} \mathrm{O}$ (a) and salinity (b) along $79^{\circ} \mathrm{N}$ in the Fram Strait observed during the late summer periods of 1998,2004 and 2005. The bottom axes represent longitude. Station positions are show as red dots. The labeled contours denote the fractions of MW (a), and SIM (positive) and IFB (negative; b). The $0^{\circ} \mathrm{C}$ isotherm is represented by the thick black line.

\subsection{Water mass content}

To quantify the content of the different water masses in the western Fram Strait during our surveys we employ a threeend-member balance involving salinity and $\delta^{18} \mathrm{O}$ (Bauch et al., 1995; Schlosser et al., 1994; Østlund and Hut, 1984). For each sample point, the following equation gives the water mass fractions of $\mathrm{AW}\left(f_{\mathrm{AW}}\right), \mathrm{MW}\left(f_{\mathrm{MW}}\right)$ and $\operatorname{SIM}\left(f_{\mathrm{SIM}}\right)$ :

$$
f_{\mathrm{AW}}+f_{\mathrm{MW}}+f_{\mathrm{SIM}}=1
$$

$f_{\mathrm{AW}} \times S_{\mathrm{AW}}+f_{\mathrm{MW}} \times S_{\mathrm{MW}}+f_{\mathrm{SIM}} \times S_{\mathrm{SIM}}=S$

$f_{\mathrm{AW}} \times \delta_{\mathrm{AW}}+f_{\mathrm{MW}} \times \delta_{\mathrm{MW}}+f_{\mathrm{SIM}} \times \delta_{\mathrm{SIM}}=\delta ;$

$S$ and $\delta$ denote salinity and $\delta^{18} \mathrm{O}$ values, respectively, and no subscripts denote the values measured 
at the sample point. We choose the following endmember values based on Bauch et al. (1995) and Ekwurzel et al. (2001): $\quad S_{\{\text {AW,MW,SIM }\}}=\{34.92,0,3\}$ and $\delta_{\{\mathrm{AW}, \mathrm{MW}, \mathrm{SIM}\}}=\{0.3,-18$, surf +2.1$\} \%$ o, where "surf" denotes the surface value at the sampling site. The fraction related to sea ice, $f_{\text {SIM }}$, can be either positive or negative, denoting SIM and IFB, respectively. $\delta_{\text {SIM }}$ was chosen as outlined in Appendix B, and errors from uncertainties in the endmember properties are detailed in Appendix A.

We find the maximum $f_{\mathrm{MW}}$ over the shelf and the shelf edge at depths of less than $25 \mathrm{~m}$ (Fig. 3a). Near the surface, we observe near-zero or even positive $f_{\mathrm{SIM}}$, manifesting summer melting (Fig. 3b). IFB is mostly found between $50 \mathrm{~m}$ to $100 \mathrm{~m}$, with $f_{\mathrm{SIM}}$ as low as -0.08 (Fig. $3 \mathrm{~b}$ ).

We define the inventory of MW for each profile by

$H_{\mathrm{MW}}=\int_{z=0 m}^{400 \mathrm{~m}} f_{\mathrm{MW}} d z$,

where $z$ represents depth.

The inventory for SIM, $H_{\text {SIM }}$, is defined in the same manner. The results show that $H_{\text {SIM }}$ is nearly always negative (Fig. 4), meaning that more IFB than SIM is present in most of the profiles. The inventories co-vary along the section, as pointed out for the 1998 data by Meredith et al. (2001). Most of the MW and IFB is located on the shelf, although the inventories have minima over shallow topography, for example around $15^{\circ} \mathrm{W}$. Only some small lenses of MW or SIM/IFB are found east of $\sim 4^{\circ} \mathrm{W}$; therefore, the analysis in the following sections will only consider the strait west of $4^{\circ} \mathrm{E}$.

\section{Transport of FW components}

\subsection{Velocity distribution}

In order to evaluate the impact of the various data sources used for the FEMSECT velocity estimate, we discuss solutions derived from different subsets of data:

A Temperature and salinity profiles from the CTD surveys and monthly averaged mooring velocities.

B Same as solution A and, additionally, detided hourlyaveraged velocities from the vessel-mounted ADCP surveys.

These solutions will be referred to as A and B for the remainder of this work.

The maximum southward velocities in each of our estimates ranged from 20 to $40 \mathrm{~cm} / \mathrm{s}$ (Fig. 5). Geostrophic estimates alone (not shown) were at the higher end of this range, but the constraints of the monthly mean mooring velocities lead to a reduction in solution A (Fig. 5a to c). However, solution B showed velocities of similar magnitude as the geostrophic estimate west of the EGF (Fig. 5d to e). The vessel-mounted ADCP velocities in solution B introduce not
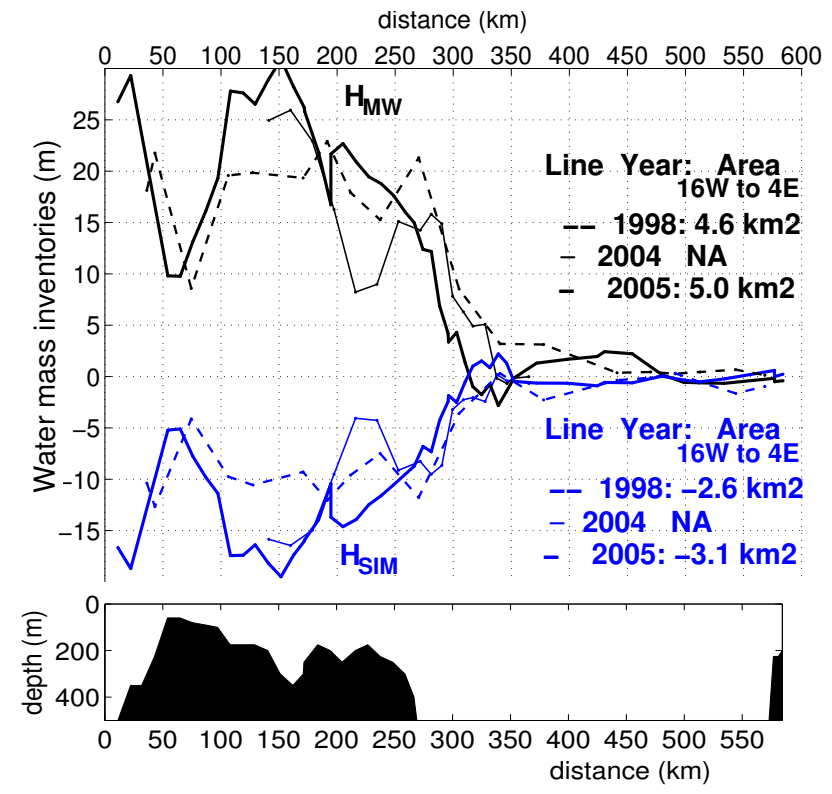

18W16W14W12W10W 8W 6W 4W 2W 0E 2E 4E $6 \mathrm{E}$ 8E

Fig. 4. Water mass inventories of $\mathrm{MW}\left(H_{\mathrm{MW}}\right.$; black lines) and SIM/IFB ( $H_{\text {SIM }}$; blue lines) along the $79^{\circ} \mathrm{N}$ sections in the Fram Strait for the years 1998 (dashed lines), 2004 (thin lines) and 2005 (thick lines). The bottom panel shows the topography along the section from the IBCAO database. For 2005 and 1998 the integrated water mass content ("Area”) between $16.3^{\circ} \mathrm{W}$ and $4^{\circ} \mathrm{E}$ was calculated. No value is given for 2004 as measurements only extended to $12^{\circ} \mathrm{W}$.

only higher barotropic velocities on the shelf. They also influence the baroclinic structure through the thermal wind balance and subsequent adjustment of the temperature and salinity fields in FEMSECT.

East of the EGF, we observed alternating bands of northand southward velocity (Fig. 5), that have been associated with Recirculating Atlantic Water from the West Spitsbergen Current (e.g. Fahrbach et al., 2001; Losch et al., 2005). Above the continental slope west of the EGF the flow was predominantly southward in all years (Fig. 5). The width of the southward flow above the slope, defined by the distance between the zero isotach on either side, was approximately $100 \mathrm{~km}$ in 2004 and 2005 (Fig. 5b, c, e and f). This is in agreement with velocity from lowered ADPC profiles (Nilsson et al., 2008) and annually averaged velocities from mooring data (Fahrbach et al., 2001). West of the shelf edge, much of the flow was southward in all years, although some northward flow was observed (Fig. 5). In particular, solution A (Fig. 5c) showed alternating south- and northward flow over the continental slope and parts of the shelf. We observed a strong northward current close to the Greenland coast in 2005 in solution B (Fig. 5f). Budéus et al. (1997) also found this feature, the Northeast Greenland Coastal Current 

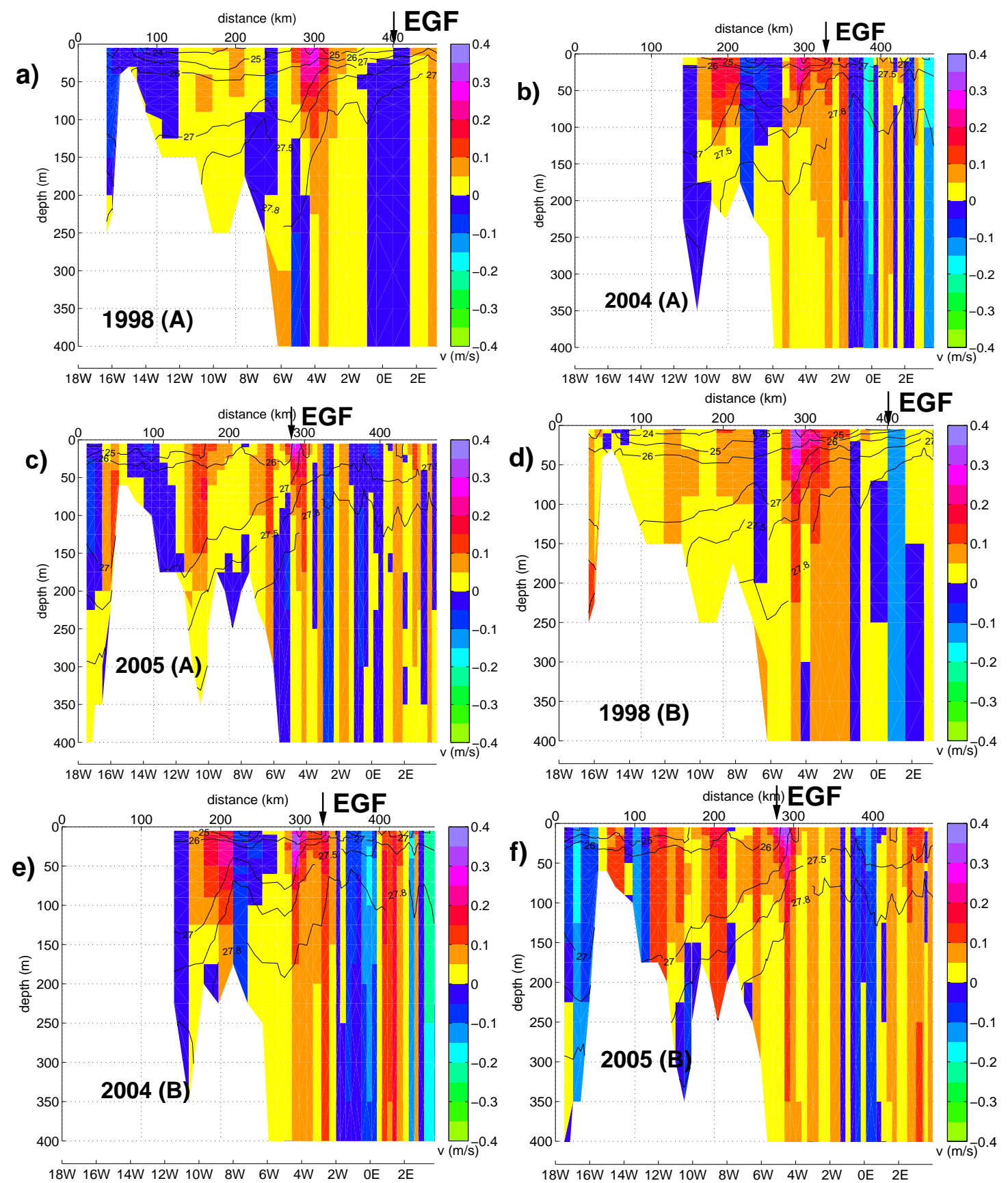

Fig. 5. Meridional velocity (colors, positive southward) and $\sigma_{\theta}$ (contours, in $\mathrm{kg} / \mathrm{m}^{3}$ ) section of the upper $400 \mathrm{~m}$ in the Fram Strait near $79^{\circ} \mathrm{N}$ (see Fig. 1), as estimated by FEMSECT: Solution A (without vessel-mounted ADCP data) for 1998 (a), 2004 (b) and 2005 (c) and solution $\mathrm{B}$ (with vessel-mounted ADCP data; d-f). The position of the EGF is the surface outcrop of the $0^{\circ} \mathrm{C}$ isotherm (Fig. 3).

(NEGCC), that had been reported previously (e.g. Kiilerich, 1945).

Geostrophic calculations by Bourke et al. (1987) indicate that the circulation on the shelf is anticyclonic. However, Budéus et al. (1997) point out in their analysis of a 1993 spring/summer hydrographic survey that this circulation is not entirely closed in the south. Solution B indicates that the circulation during our surveys in 1998 and 2005 was less spatially uniform than suggested by Bourke et al. (1987) and Budéus et al. (1997). 
a)
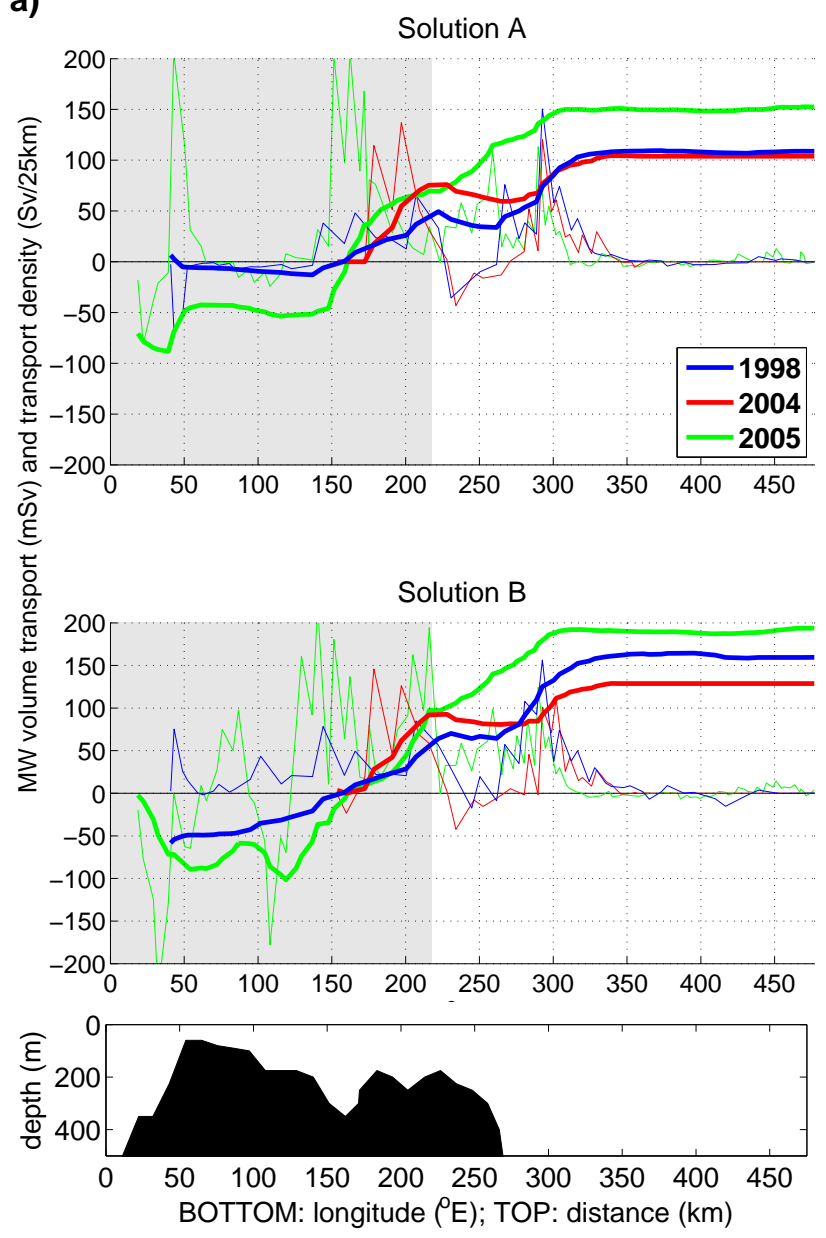

18W 16W 14W 12W 10W 8W $6 \mathrm{~W} \quad 4 \mathrm{~W} \quad 2 \mathrm{~W} \quad 0 \mathrm{E} \quad 2 \mathrm{E}$ b)
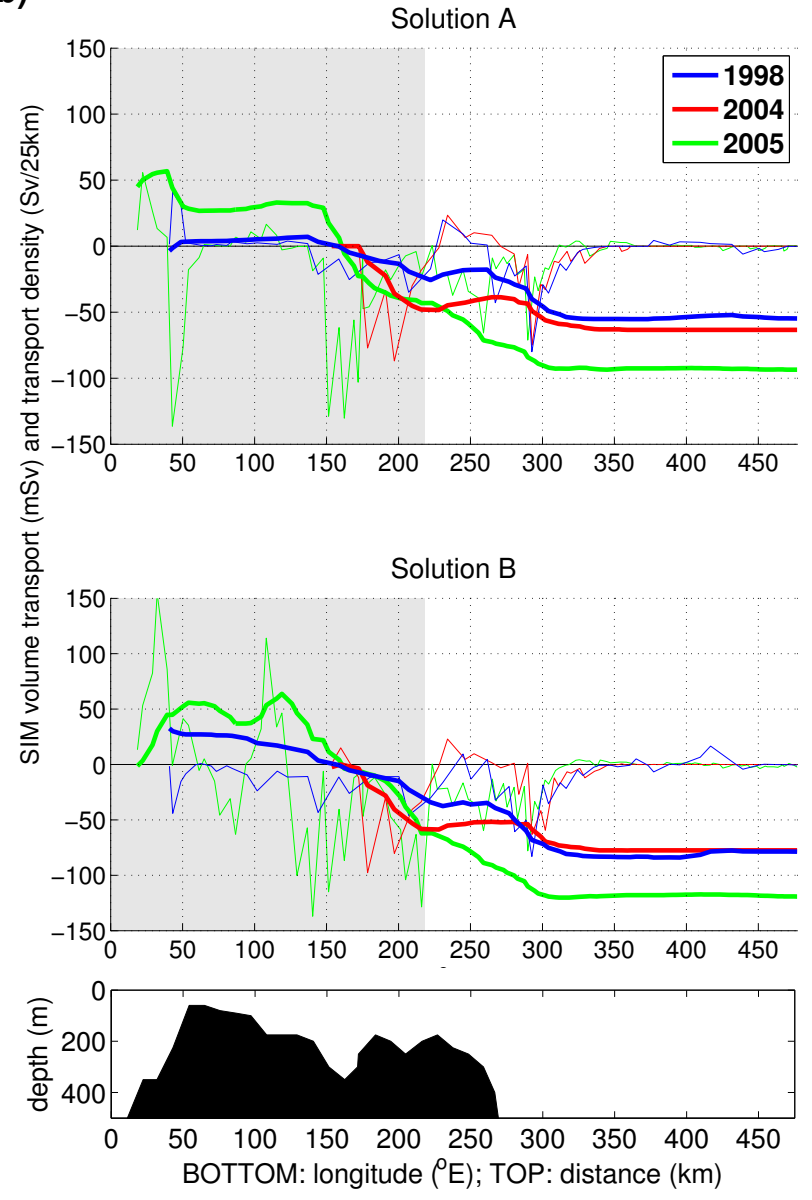

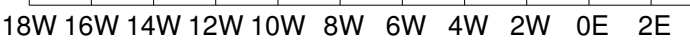

Fig. 6. Meridional volume transports of MW (a) and SIM/IFB (b) along the Fram Strait west of $4^{\circ} \mathrm{E}$ for 2004 (red), 2005 (green) and 1998 (blue). Southward transports are positive, thin lines represent transports over $25 \mathrm{~km}$ wide segments (transport density) and thick lines denote the cumulative transport from $10.6^{\circ} \mathrm{W}$ to either end of the section. Results from FEMSECT solution A and solution B are shown in the top and middle panels, respectively. The region not covered by moorings in all years is shaded in gray (in 1998, the westernmost mooring was located around $7^{\circ} \mathrm{W}$ ). The bottom panel shows the topography along the section from the IBCAO database. Error estimates are discussed in the text and given for the section transports in Table 1.

\subsection{Volume transports}

To estimate the volume transports of MW and IFB, we linearly interpolated $f_{\mathrm{SIM}}$ and $f_{\mathrm{MW}}$ onto the FEMSECT grid and multiplied the fractions by the transport fields and the transport error estimates of the model solutions. The volume transport of liquid FW was obtained in a similar way by using the fractions of FW defined by

$f_{\mathrm{FW}}=\frac{S_{\mathrm{ref}}-S}{S_{\mathrm{ref}}}$,

where $S_{\text {ref }}=S_{\mathrm{AW}}=34.92$, the salinity of the AW end-member in Eq. (2)
In all years, the majority of the MW transports were southward and occurred on the eastern shelf and over the continental slope (Fig. 6a). Whereas solution A shows mostly small transports on the remainder of the shelf, solution B shows alternating south- and northward transports. As both the velocities and inventories of MW and SIM are spatially variable (Figs. 4 and 5), both influence the distribution of the respective transports along the section. SIM was mostly negative in all years (Fig. 4), i.e. the negative SIM transports represent southward transports of IFB. Similar to the inventories, the transports of MW and IFB co-vary along the section (Fig. 6).

A caveat of our transport estimates is that the westward extension of the survey varies from year to year. In 
Table 1. Volume transports of FW, MW and SIM/IFB (mSv, positive southward) in the Fram Strait between $10.6^{\circ} \mathrm{W}$ and $4.0^{\circ} \mathrm{E}$ for each of the three years and mean. Estimates are shown for FEMSECT solution $\mathrm{A}$ and $\mathrm{B}$, and $*$ refers to transports between $7^{\circ} \mathrm{W}$ and $4.0^{\circ} \mathrm{E}$. The transport errors are based on the inverse model error estimates (Sect. 2.3). There is also an error associated with the assumption of constant end-member properties, which would lead to combined transport errors for solution B between 13 and $23 \mathrm{mSv}$ (Appendix A).

Transport estimates with the potential bias for 1998 and 2005 removed (Appendix A) are marked by + , where the average transports $\left(\right.$ Mean ${ }^{+}$) have been recalculated using values associated with Years $1998^{+}, 2004$ and $2005^{+}$for MW and Year 1998, 2004 and $2005^{+}$for IFB.

\begin{tabular}{lcccccc}
\hline \multicolumn{7}{c}{ Volume transports and errors (mSv) } \\
Year & MW & MW & SIM/IFB & SIM/IFB & FW & FW \\
- & A & B & A & B & A & B \\
\hline 1998 & $110 \pm 46$ & $160 \pm 13$ & $-50 \pm 18$ & $-80 \pm 5$ & $60 \pm 28$ & $90 \pm 6$ \\
2004 & $100 \pm 33$ & $130 \pm 10$ & $-60 \pm 15$ & $-80 \pm 5$ & $50 \pm 15$ & $60 \pm 4$ \\
2005 & $150 \pm 58$ & $190 \pm 14$ & $-90 \pm 20$ & $-120 \pm 5$ & $70 \pm 25$ & $80 \pm 6$ \\
Mean & - & $160 \pm 12$ & - & $-90 \pm 7$ & - & $80 \pm 6$ \\
$1998^{+}$ & $80 \pm 46$ & $120 \pm 13$ & - & - & - & - \\
$2005^{+}$ & $120 \pm 58$ & $150 \pm 14$ & $-60 \pm 20$ & $-90 \pm 5$ & - & - \\
Mean $^{+}$ & - & $130 \pm 12$ & - & $-60 \pm 7$ & - & - \\
$1998^{*}$ & 70 & 90 & -30 & -40 & 40 & 50 \\
$2004^{*}$ & 40 & 40 & -20 & -20 & 20 & 20 \\
$2005^{*}$ & 80 & 70 & -40 & -50 & 30 & 40 \\
\hline
\end{tabular}

2005 (solution B), the transports cumulate to zero between $18^{\circ} \mathrm{W}$ and $10.6^{\circ} \mathrm{W}$. Since the sum of the transports between $10.6^{\circ} \mathrm{W}$ and $16^{\circ} \mathrm{W}$ is approximately the same in 2005 and 1998 , we assume that also in 1998 the flow east of $10.6^{\circ} \mathrm{W}$ is balanced. This agrees with earlier statements of an anticyclonic loop (Bourke et al., 1987; Budéus et al., 1997). Therefore, we choose to calculate the mean transports only between $10.6^{\circ} \mathrm{W}$ and $4^{\circ} \mathrm{E}$.

We only consider solution B for the average, as this should give a better representation of the barotropic component of the velocities on the shelf. We obtain average MW and IFB transports of $160 \pm 12 \mathrm{mSv}\left(5000 \mathrm{~km}^{3} / \mathrm{yr}\right)$ and $90 \pm 7 \mathrm{mSv}$ $\left(2800 \mathrm{~km}^{3} / \mathrm{yr}\right)$ southward, respectively (Table 1$)$. If we remove the estimated biases due to PW presence in 1998 and due to the interpolation of $\delta^{18} \mathrm{O}$ values in 2005 (Appendix A) we obtain averages of $130 \pm 12 \mathrm{mSv}\left(4100 \mathrm{~km}^{3} / \mathrm{yr}\right)$ and $60 \pm 7 \mathrm{mSv}\left(1900 \mathrm{~km}^{3} / \mathrm{yr}\right)$, respectively. The IFB transport means that water in the Arctic, proceeding towards the Fram Strait, has been transformed to sea ice at this rate. Whether it is then exported as ice or still retained in the Arctic cannot be said from these data. In any case, the liquid FW transport is, therefore, a combination of the MW and IFB transports. The result is a southward liquid FW transport through the Fram Strait of $80 \pm 6 \mathrm{mSv}$ or $2500 \mathrm{~km}^{3} / \mathrm{yr}$ (Table 1). This is at the upper end of the FW transport estimates reported in the literature (Dickson et al., 2007; Serreze et al., 2006). Estimates based on mooring observations alone are much lower than ours, with an annual mean of approximately $30 \mathrm{mSv}\left(1000 \mathrm{~km}^{3} / \mathrm{yr}\right.$, reference salinity of 34.9 ; Holfort et al., 2008), varying between $20 \mathrm{mSv}$ to $42 \mathrm{mSv}$ during July, August and September (de Steur et al., 2009). These moorings are a subset of those used to obtain the velocity data in our study. If we calculate the transports only for the region covered by these moorings, they account for only $\frac{1}{3}$ to $\frac{2}{3}$ of the transports of MW and IFB between $10.6^{\circ} \mathrm{W}$ and $4^{\circ} \mathrm{W}$ (Table 1). For the summer months, our analysis using FEMSECT allows us to capture the transport outside the region covered by the moorings. Our results are in agreement with estimates of FW transports from direct velocity measurements during winter (Nilsson et al., 2008). From a survey in May 2002 Nilsson et al. obtain a southward FW transport (reference salinity of 35) of $50 \mathrm{mSv}$ from Lowered ADCP measurements and $80 \mathrm{mSv}$ from geostrophy referenced to zero bottom velocity. Furthermore, model simulations by Gerdes et al. (e.g. 2008) are in agreement with the magnitudes of our FW transport estimates.

\section{Variability}

\subsection{Content of MW and IFB}

Our observations in the Fram Strait span a time period of almost a decade, and we will analyze our results with respect to the changes in the the upper ocean circulation in the Arctic from the mid-1990s until 2005.

In 2004 and $2005, \delta^{18} \mathrm{O}$ values at $\sim 79^{\circ} \mathrm{N}$ were lower than in 1998, in particular at depths $>100 \mathrm{~m}$ over the shelf (Fig. 3a), and the depth range of salinities between 32.8 and 33.2 broadened (Fig. 3b). This means that more MW was present on the shelf in 2005 than in 1998 (Fig. 3a and Fig. 4). On the continental slope, on the other hand, the inventories of MW and IFB in 2004/2005 were lower than in 1998 (Fig. 4). In 2005 the area of MW between $16^{\circ} \mathrm{W}$ and $4^{\circ} \mathrm{W}$ was $8 \%$ larger than in 1998; the area was calculated by integrating $f_{\mathrm{MW}}$ that had been interpolated onto the triangulated FEMSECT grid (Fig. 4). Hence this area only changed marginally between the 1998 and 2005 estimates, but MW was distributed onto the shelf. The properties of FUHW changed to higher salinity and lower $\delta^{18} \mathrm{O}$ values (Fig. 2b). This means that more brine from ice formation contributed to FUHW, i.e. we found higher concentrations of IFB in 2004 and 2005 relative to 1998 (Fig. 3b), and the area covered by IFB between $16^{\circ} \mathrm{W}$ and $4^{\circ} \mathrm{W}$ was about $20 \%$ larger in 2005 than in 1998 (Fig. 4). In 2005 a significant amount of IFB and MW was also found between $16^{\circ} \mathrm{W}$ to $18^{\circ} \mathrm{W}$, but the 1998 survey did not extend this far west. 


\subsection{Transports and dynamics}

Both FEMSECT solutions with and without vessel-mounted ADCP measurements show that the southward transports of MW and IFB increased between 1998 and 2005 (Table 1), with those in 2004 being higher (lower) than the 1998 values if we consider (ignore) the potential bias explained in Appendix A. Below we discuss if the changes in water mass transports are associated with changes in velocity or water mass concentration for solution B.

The north-south velocity bands around the shelf edge in 2004 and 1998 and the shape of the $0^{\circ} \mathrm{C}$-isotherm suggests that an eddy was present within the EGC that was not evident in 2005 (Fig. 5). This and the strong southward velocity around $10^{\circ} \mathrm{W}$ lead to the high MW and IFB transports in 2005 (Fig. 6). The higher velocities were associated with a change in the slope of the EGF between the 1998 and 2005 observations, seen in the westward displacement of the surface outcrop of the $0^{\circ} \mathrm{C}$ isotherm (Fig. 3b). On the shelf, the cold, fresh PSW layer deepened to almost the full depth, whereas over the continental slope, in the vicinity of the EGF, this layer shallowed. At the same time, isopycnals became steeper and horizontal pressure gradients were stronger in 2005 than in all other years. Hence, the southward baroclinic geostrophic velocities were stronger. In a large scale model simulation, Köberle and Gerdes (2007) found periods of high southward FW transports between 1948 and 2001 to be associated with an anomalously deep PSW layer and a steep EGF.

Since the MW content east of $10.6^{\circ} \mathrm{W}$ was lower in 2005 than in 1998, one may expect a decrease in southward MW transports in this part of the section. However, this decrease was not observed, as the strong southward velocities in 2005 lead to higher MW transports.

\subsection{MW and IFB pathways}

The fate of riverine MW in the Arctic has been simulated using a model from the NAOSIM suite that included $\delta^{18} \mathrm{O}$ as a passive tracer (Karcher et al., 2006). The ocean and sea ice simulation is driven by NCEP/NCAR atmospheric reanalysis data for the period 1948 to 2004. For the initialization of $\delta^{18} \mathrm{O}$ a linear relation with salinity derived from observational data has been applied (D. Bauch, personal communication, 2004). Inflow concentrations for $\delta^{18} \mathrm{O}$ vary from $-15 \%$ o for Scandinavian rivers to $-22 \%$ o for the easternmost Arctic rivers. For Atlantic Water at the southern boundary near $48^{\circ} \mathrm{N}$, a $\delta^{18} \mathrm{O}$ value of $1 \%$ o has been applied. In this experiment no fractionation of $\delta^{18} \mathrm{O}$ due to ice formation or melt have been taken into account. Here, we concentrate on the interpretation of the most recent decade. During the mid1990s river water accumulated in the Siberian shelf areas. In the late 1990s, this water, represented by very low values of $\delta^{18} \mathrm{O}$, penetrated into the central Arctic basin north of the East Siberian Sea (Fig. 7a). Subsequently, this river water advected (2001, Fig. 7b) along the Transpolar Drift path, and reached the northern shores of Greenland in 2003 (not shown). In August 2004, the strong river water signal in the model can be seen in the northern Fram Strait, but did not yet reach the latitude of our observations further south (Fig. 7c). The simulations suggests that the larger MW transports we observe in 2005 relative to 1998 may in part be a consequence of the changing pathways of Eurasian river runoff since the mid-1990s and points out a buffering of runoff inside the Arctic Ocean. The simulation by Köberle and Gerdes (2007) identifies co-variability of the accumulation of FW on the shelves of the Arctic Ocean, the thickness of the fresh PSW layer in the western Fram Strait and high southward FW transport. However, the forcing and processes that lead to such a distribution of FW remain, as yet, ambiguous.

The ratio of the transports of IFB and MW through the Fram Strait section is similar in all years, between $\frac{1}{1.5}$ to $\frac{1}{2}$ (see Fig. 6), suggesting some systematic covariability between ice formation and the accumulation of river water in parts of the Arctic.

\section{Concluding remarks}

This work presents new estimates of the amount, the components and the meridional transport of freshwater along $\sim 79^{\circ} \mathrm{N}$ in the western Fram Strait. Based on late summer CTD, $\delta^{18} \mathrm{O}$, mooring and ship-borne ADCP observations from 1998, 2004 and 2005, we distinguish contributions from meteoric sources and fractions that were modified by ice formation. The water mass distributions were combined with volume transport estimates from the FEMSECT inverse model. This method allowed us to obtain meridional water mass transports for the whole width of the EGC, utilizing all available velocity and hydrography data in a physically consistent way.

On average, the liquid FW transport was $80 \pm 6 \mathrm{mSv}$ or $2500 \mathrm{~km}^{3} / \mathrm{yr}$ (reference salinity $=34.92$ ). It varied by about $40 \%$ between 2004 and the years 1998 and 2005, respectively (Table 1). Simulations with an ice-ocean model driven by NCEP forcing illustrate that this was caused by the temporal buffering of river water on the Arctic shelves. In the late 1990s, river water was held up in the East Siberian Sea and later transferred in the transpolar drift as a positive anomaly. In August 2004, an increased amount of river water arrived north of the Fram Strait. Later in 2004 and most notably in 2005, as shown by the observations, high amounts of MW passed the $79^{\circ} \mathrm{N}$ latitude.

While the observed FW transport was almost the same in 1998 and 2005, the MW transport was $20 \%$ to $25 \%$ higher in 2005. However, the higher MW transport was largely compensated by a respective increase in the IFB fraction, suggesting that in phases when river water is retained on the shelves, more ice is formed at the same time. 

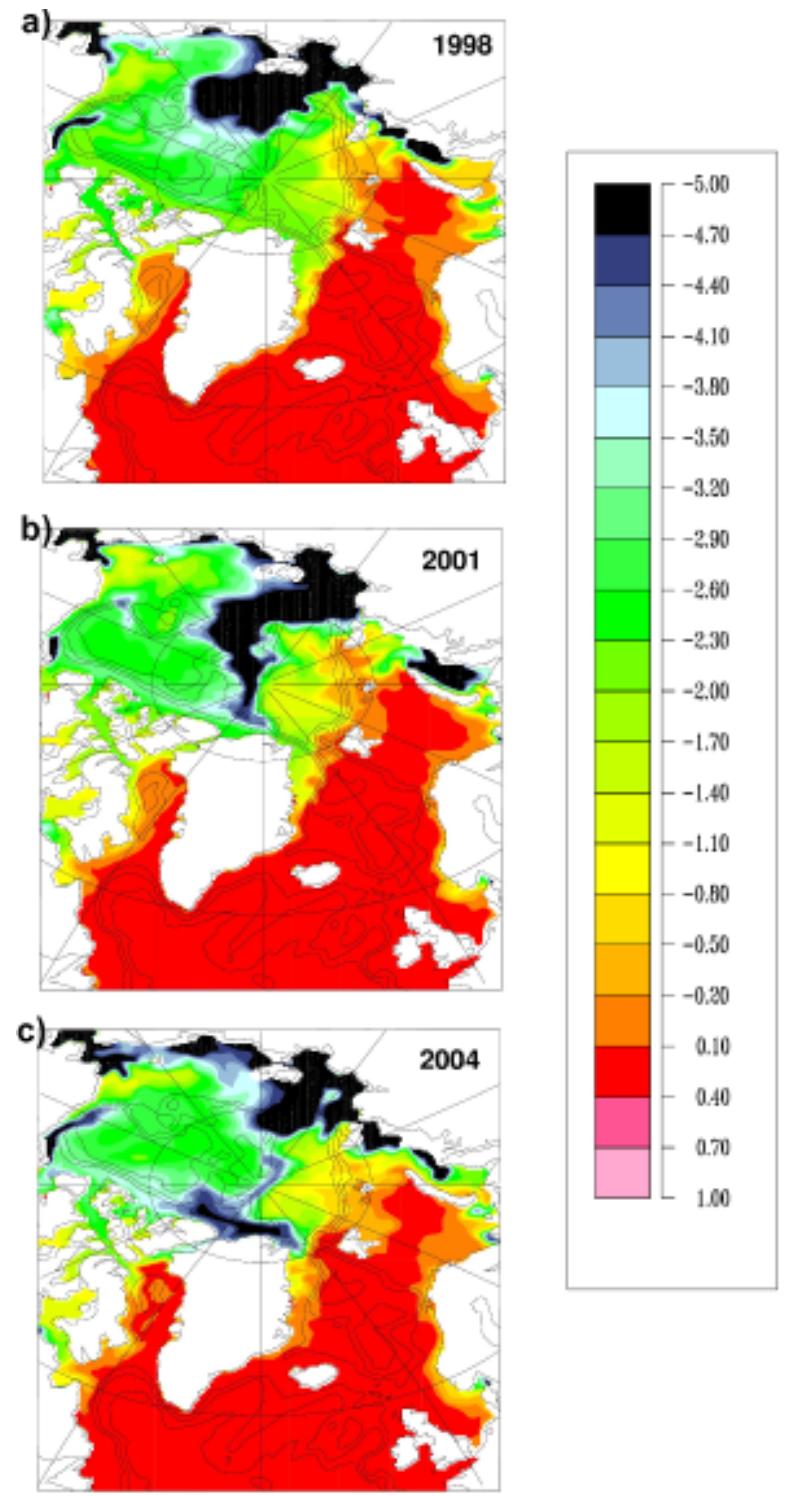

Fig. 7. August near-surface $\delta^{18} \mathrm{O}$ distribution (in \%o) in the Arctic Ocean as simulated by NAOSIM for 1998 (a), 2001 (b) and 2004 (c).

In addition, the zonal distribution of the FW flow in Fram Strait was different in the years of equal transport: In 2005, the vertical extent of MW was greater on the shelf than above the continental slope, but the velocity was was higher over the slope. Alternating north- and southward transports, confirming an anticyclonic shelf circulation as inferred from hydrographic measurements by (Budéus et al., 1997; Bourke et al., 1987), were observed only west of about $10^{\circ} \mathrm{W}$. We conclude that in some years a considerable part of the net southward FW transport takes place on the shelf rather than on the continental slope.

\section{Appendix A}

\section{Errors associated with the choice of end-members}

The uncertainty in the water mass fractions calculated using Eqs. (1 to 3) depends on the estimated variation of our endmember properties relative to the constants used in the equations. The AW we observed in the Fram Strait showed some $\delta^{18} \mathrm{O}$ values up to $0.7 \%$ o but was generally around $0.3 \%$ o (see Fig. $2 \mathrm{~b})$; hence, uncertainty in this end-member $\left(S_{a}\right)$ pro-

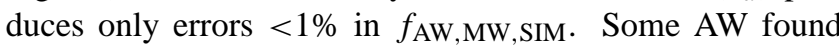
in the central Fram Strait sections had salinity greater than $S_{a}$. This water may have been Recirculating Atlantic Water from the Yermak Plateau, that had not circumvented the Arctic (see also Rudels et al., 2002; Manley, 1995). Although the inflow properties of AW changed during the time period covered by our observations, those changes of the $\delta^{18} \mathrm{O}$ and salinity distribution are not expected to have circumvented the Arctic circulation system during that time. This suggests that the AW fraction present within the PSW is close to the one we obtain from Eqs. (1) to (3). The meteoric endmember varies between different rivers and regions of precipitation, between -24 to $-13 \%$, although the four largest rivers and high-latitude precipitation lie approximately between -16 to $-20 \%$ o (Ekwurzel et al., 2001). We expect much of the water from the Eurasian rivers to mix before leaving the shelf, so that the MW arriving in the Fram Strait can be expected to have $\delta^{18} \mathrm{O}$ values close to $-18 \%$. Sea ice formation and transport depend on the Polar Mixed-layer circulation and the ice drift. If formed in the Eurasian shelf regions, sea ice may contain significant amounts of river water (e.g. Eicken et al., 2000). However, the riverine part of MW is mixed relatively fast as it enters the Arctic (Bauch et al., 2005), so that the mean $\delta^{18} \mathrm{O}$ value of sea ice is assumed closer to that of AW than MW; for example, Bauch et al. (1995) states Laptev Sea surface values as low as $-2 \%$, still higher than those found in the central Arctic. On the other hand, Eicken et al. (2000) mention minimum sea-ice $\delta^{18} \mathrm{O}$ of $-3.5 \%$ in the Laptev Sea.

We assume the following range of values for our endmembers, similar to the ones used by Ekwurzel et al. (2001): $34.92<S_{\mathrm{AW}}<35.00, S_{\mathrm{MW}}=0,2<S_{\mathrm{SIM}}<4,0.2<\delta \mathrm{AW}<0.4$, $-20<\delta \mathrm{MW}<-16$ and $-3.5<\delta \mathrm{SIM}<0$. Sensitivity tests conducted on Eqs. (1 to 3), based on these ranges of endmember values, lead to error estimates of $0.002,0.016$ and 0.016 for the fractions of AW, MW and IFB, respectively. Multiplying these error estimates with the FEMSECT transport fields, we can obtain additional errors in the water mass transports.

The presence of PW could introduce additional errors. Bauch et al. (1995) compared the results of the three endmember balance and a four end-member one, that included the PW fraction and observations of Silica content. Bauch et al. (1995) show for their stations closest to the Fram Strait where PW was present that the three end-member balance 
overestimates the contributions of $f_{\mathrm{MW} \text {,SIM }}$ by up to $25 \%$. Falck et al. (2005) showed that PW had been present in the Fram Strait in 1998 but had disappeared by 2004. Therefore, our MW transport estimates in 1998 may in reality have been lower.

As the presence of PW in 1998 and the reconstruction of $\delta^{18} \mathrm{O}$ values in 2005 lead to a positive bias in our transports, we will not include these in our error estimates but consider the respective transport values both with and without these biases. Hence our final error estimate for the transports are a combination of transport errors of the FEMSECT solutions (Table 1) and the errors associated with the end-member uncertainties. The combined error estimates are within 17 to $23 \mathrm{mSv}$ and 13 to $23 \mathrm{mSv}$ for the MW and SIM/IFB transports, respectively.

\section{Appendix B}

\section{Fractionation of oxygen isotopes during ice formation}

The $\delta^{18} \mathrm{O}$ fractionation factor of water upon freezing is taken to be $\sim 1.0021$, meaning that sea ice shows an increase in $\delta^{18} \mathrm{O}$ by $+2.1 \%$ relative to the water it was formed from. This value has been observed in the Arctic (Melling and Moore, 1995; Østlund and Hut, 1984) and is close to laboratory values of $\sim 1.0030$ (O’Neil, 1968) or $\sim 1.0034 \pm 0.0003$ (Majoube, 1970). As the $\delta^{18} \mathrm{O}$ value of the water the ice was formed from is not known due to the independent movement of sea ice, it is assumed that it is close to the surface value at the sampling site. This assumption is only a first order approximation but seems valid in the presence of relatively small $\delta^{18} \mathrm{O}$ gradients within the Arctic ocean surface waters, relative to the low $\delta^{18} \mathrm{O}$ inherent to meteoric water (Meredith et al., 2001).

In a study of landfast ice in the Laptev Sea Eicken et al. (2005) estimate a bulk value of $+2.05 \%$ o increase in $\delta^{18} \mathrm{O}$ for average ice growth rates, using an ice-growth and isotope fractionation model by Eicken (1998). In autumn, 2007, samples taken near and from sea ice showed an average value of $+1.7 \%$ with some values as low as $+0.4 \%$ o in the central Arctic (Schauer, 2008). This suggests that the value of $+2.1 \%$ by Melling and Moore (1995) is more appropriate than the $>3 \%$ o seen in the laboratory experiments, that are for FW only.

Acknowledgements. We thank the participants of Polarstern cruises ARK XIV/2, ARK XX/2 and ARK XXI/1b for their assistance in obtaining the data. This work was supported by the Co-Operative Project "The North Atlantic as Part of the Earth System: From System Comprehension to Analysis of Regional Impacts" funded by the German Federal Ministry for Education and Research (BMBF), the European Union MAST III Programme VEINS (Variability of Exchanges in the Northern Seas), contract number MAS3-CT96-0070 and the Fifth Framework Programme project ASOF-N (Arctic-Subarctic Ocean Flux Array for European Climate: North), contract number EVK2-CT-200200139.

Edited by: K. J. Heywood

\section{References}

Aagaard, K. and Carmack, E. C.: The role of sea ice and other fresh water in the Arctic circulation, J. Geophys. Res., 94, 1448514498, 1989.

Anderson, L. G., Jutterström, S., Kaltin, S., Jones, E. P., and Björk, G.: Variability in river runoff distribution in the Eurasian Basin of the Arctic Ocean, J. Geophys. Res., 109, C01016, doi: 10.1029/2003JC001773, 2004.

Bauch, D., Schlosser, P., and Fairbanks, R. G.: Freshwater balance and the sources of deep and bottom waters in the Arctic Ocean inferred from the distribution of $\mathrm{H}_{2}^{18} \mathrm{O}$, Progress Oceanogr., 35, 53-80, 1995.

Bauch, D., Erlenkeuser, H., and Andersen, N.: Water mass processes on Arctic shelves as revealed from $\delta_{18} \mathrm{O}$ of $\mathrm{H}_{2} \mathrm{O}$, Global Planet. Change, 48, 165-174, 2005.

Behrendt, A.: Comparison of the Current Field in Fram Strait derived from ADCP Measurements and Mooring Data, Master's thesis, University of Bremen, 2008.

Bourke, R. H., Newton, J. L., Paquette, R. G., and Tunnicliffe, M. D.: Circulation and water masses of the East Greenland Shelf, J. Geophys. Res., 92, 6729-6740, 1987.

Brauch, J. P. and Gerdes, R.: Reaction of the northern North Atlantic and Arctic oceans to a sudden change of the NAO, J. Geophys. Res., 110, C11018, doi:10.1029/2004JC002436, 2005.

Budéus, G., Schneider, W., and Kattner, G.: Distribution and exchange of water masses in the Northeast Water Polynya (Greenland Sea), 10, 123-138, 1997.

de Steur, L., Hansen, E., Gerdes, R., Karcher, M., Fahrbach, E., and Holfort J.: Freshwater fluxes in the East Greenland Current: a decade of observations, in preparation, 2009.

Dickson, R., Rudels, B., Dye, S., Karcher, M., Meincke, J., and Yashayaev, I.: Current estimates of freshwater flux through Arctic and subarctic seas, Progress in Oceanography, 73, 210-230, doi:10.1016/j.pocean.2006.12.003, 2007.

Dodd, P.: Freshwater Transport in the East Greenland Current, Ph.D. thesis, University of East Anglia, 2008.

Dodd, P., Heywood, K. J., Meredith, M. P., Naveira Garabato, A. C., Marca, A. D., and Falkner, K. K.: The Sources and Fate of Freshwater Exported in the East Greenland Current, Geophys. Res. Lett., in review, 2009.

Eicken, H.: Factors determining microstructure, salinity and stableisotope composition of Antarctic sea ice: deriving modes and rates of ice growth in the Weddell Sea, in: Antarctic sea ice physical processes, edited by: Jeffries, M. O., vol. 74 of AGU Antarct. Re. Ser., 89-122, 1998.

Eicken, H., Kolatschek, J., Freitag, J., Lindemann, F., and Kassens, H.: A key source area and constraints on entrainment for basinscale sediment transport by Arctic sea ice, Geophys. Res. Lett., 27, 1919-1922, 2000.

Eicken, H., Dmitrenko, I., Tyshko, K., Darovskikh, A., Wierking, W., Lahak, U., Groves, J., and Kassens, H.: Zonation of the Laptev Sea landfast ice cover and its importance in a frozen estuary, Global Planet. Change, 48, 55-83, 2005. 
Ekwurzel, B., Schlosser, P., Mortlock, R. A., and Fairbanks, R. G.: River runoff, sea ice meltwater, and Pacific water distribution and mean residence times in the Arctic Ocean, J. Geophys. Res., 106, 9075-9092, 2001.

Fahrbach, E., Meincke, J., Østerhus, S., Rohardt, G., Schauer, U., Tverberg, V., and Verduin, J.: Direct measurements of volume transports through Fram Strait, Polar Res., 20, 217-224, 2001.

Fahrbach, E., Rohardt, G., and Sieger, R.: 25 Years of Polarstern Hydrography (1982-2007), 5, Alfred Wegener Institute for Polar and Marine Research: Bremerhaven, doi:10013/epic.30213. d001, 2007.

Falck, E., Kattner, G., and Budèus, G.: Disappearance of Pacific Water in the northwestern Fram Strait, Geophys. Res. Lett., 32, L14619, doi:10.1029/2005GL023400, 2005.

Foldvik, A., Aagaard, K., and Tørresen, T.: On the velocity field of the East Greenland Current, Deep-Sear Res., 35, 1335-1354, 1988.

Gerdes, R., Karcher, M., Köberle, C., and Fieg, K.: Simulating the long term variability of liquid freshwater export from the Arctic Ocean, in: Arctic-Subarctic Ocean Fluxes: Defining the role of the Northern Seas in climate, edited by: Dickson, R. R., Meincke, J., and Rhines, P., chap. 17, 405-425, Springer Science and Business Media, 2008.

Guay, C. K. H., Falkner, K. K., Muench, R. D., Mensch, M., Frank, M., and Bayer, R.: Wind-driven transport pathways for Eurasian Arctic river discharge, J. Geophys. Res., 106, 11469-11480, 2001.

Haak, H., Jungclaus, U., Mikolajewicz, U., and Latif, M.: Formation and propagation of great salinity anomalies, Geophys. Res. Lett., 30, 1473, doi:10.1029/2003GL01765, 2003.

Häkkinen, S.: A simulation of the thermohaline effects of a great salinity anomaly, J. Climate, 12, 1781-1795, 1999.

Häkkinen, S. and Proshutinsky, A.: Freshwater content variability in the Arctic Ocean, J. Geophys. Res., 109, C03051, doi:10.1029/ 2003JC001940, 2004.

Holfort, J., Hansen, E., Østerhus, S., Dye, S., Jonsson, S., Meincke, J., Mortensen, J., and Meredith, M.: Freshwater fluxes east of Greenland, in: Arctic-Subarctic Ocean Fluxes: Defining the role of the Northern Seas in climate, edited by Dickson, R. R., Meincke, J., and Rhines, P., chap. 11, 263-287, Springer Science and Business Media, 2008.

Jakobsson, M., Macnab, R., Mayer, M., Anderson, R., Edwards, M., Hatzky, J., Schenke, H.-W., and Johnson, P.: An improved bathymetric portrayal of the Arctic Ocean: Implications for ocean modeling and geological, geophysical and oceanographic analyses, Geophys. Res. Lett., 35, L07602, doi:10.1029/2008GL033520, 2008.

Jones, E. P., Anderson, L. G., Jutterström, S., Mintrop, L., and Swift, J. H.: Pacific fresh water, river water and sea ice meltwater across Arctic Ocean basins: Results from the 2005 Beringia Expedition, J. Geophys. Res., 113, C08012, doi:10. 1029/2007JC004124, 2008a.

Jones, E. P., Anderson, L. G., Jutterström, S., and Swift, J. H.: Sources and distribution of freshwater in the East Greenland Current, Progress in Oceanography, 78, 37-44, doi:10.1016/j. pocean.2007.06.003, 2008b.

Karcher, M., Gerdes, R., Kauker, F., Köberle, C., and Yashayaev, I.: Arctic Ocean change heralds North Atlantic freshening, Geophys. Res. Lett., 32, L21606, doi:10.1029/2005GL023861, 2005.
Karcher, M., Gerdes, R., and Kauker, F.: Modeling of $\delta_{18} \mathrm{O}$ and ${ }_{99} \mathrm{Tc}$ dispersion in Arctic and subarctic seas, ASOF Newsletter, 5, available from: http://asof.npolar.no, 2006.

Kiilerich, A.: On the hydrography of the Greenland Sea, Medd. Groenl., 144, 1-63, 1945.

Köberle, C. and Gerdes, R.: Simulated variability of the Arctic Ocean fresh water balance 1948-2001, J. Phys. Oceanogr., 37, 1628-1644, doi:10.1175/JPO03063.1, 2007.

Losch, M., Sidorenko, D., and Beszczynska-Möller, A.: FEMSECT: An inverse section model based on the finite element method, J. Geophys. Res., 110, C12023, doi:10.1029/ 2005JC002910, 2005.

Mackensen, A.: Oxygen and carbon stable isotope tracers of Weddell Sea water masses: new data and some paleoceanographic implications, Deep-Sea Res. I, 48, 1401-1422, 2001.

Majoube, M.: Fractionation factor of ${ }^{18} O$ between water vapor and ice, Nature, 226, 1242, doi:10.1038/2261242a0, 1970.

Manley, T. O.: Branching of Atlantic Water within the GreenlandSpitsbergen Passage: An estimate of recirculation, J. Geophys. Res., 100, 20627-20634, 1995.

Melling, H. and Moore, R. M.: Modification of halocline source waters during freezing on the Beaufort Sea shelf: evidence from oxygen isotopes and dissolved nutrients, Cont. Shelf. Res., 15, 89-113, 1995.

Meredith, M., Heywood, K., Dennis, P., Goldson, L., White, R., Fahrbach, E., Schauer, U., and Østerhus, S.: Freshwater fluxes through the western Fram Strait, Geophys. Res. Lett., 28, 16151618, 2001.

Morrison, J., Steele, M., Kikuchi, T., Falkner, K., and Smethie, W.: Relaxation of central Arctic Ocean hydrography to pre-1990s climatology, Geophys. Res. Lett., 33, L17604, doi: 10.1029/2006GL026826, 2006.

Nilsson, J., Björk, G., Rudels, B., Winsor, P., and Torres, D.: Liquid freshwater transport and Polar Surface Water characteristics in the East Greenland Current during the AO-O2 Oden expedition, Progress Oceanogr., 78, doi:10.1016/j.pocean.2007.06.002, 2008.

O'Neil, J. R.: Hydrogen and oxygen isotope fractionation between icena and water, J. Phys. Chem., 72, 3683-3684, 1968.

Østlund, H. G. and Hut, G.: Arctic Ocean water mass balance from isotope data, J. Geophys. Res., 89, 6373-6381, 1984.

Padman, L. and Erofeeva, S.: A barotropic inverse tidal model for the Arctic Ocean, Geophys. Res. Lett., 31, L02303, doi:10.1029/ 2003GL019003, 2004.

Rudels, B., Fahrbach, E., Meincke, J., Budèus, G., and Ericksson, P.: The East Greenland Current and its contribution to the Denmark Strait overflow, ICES J. Mar. Sci., 59, 1133-1154, doi: 10.1006/jmsc.2002.1284, 2002.

Rudels, R., Jones, E. P., Schauer, U., and Ericksson, P.: Atlantic sources of the Arctic Ocean surface and halocline waters, Polar Res., 23, 181-208, 2004.

Schauer, U.: The Expedition ARKTIS-XXII/2 of the Research Vessel "Polarstern" in 2007, vol. 579 of Reports on polar and marine research, Alfred-Wegener Institute for Polar and Marine Research: Bremerhaven, 2008.

Schauer, U., Fahrbach, E., Østerhus, S., and Rohardt, G.: Arctic warming through the Fram Strait: Oceanic heat transport from 3 years of measurements, J. Geophys. Res., 109, C06026, doi: 10.1029/2003JC001823, 2004. 
Schlichtholz, P. and Houssais, M.-N.: An overwiew of the $\theta$ - S correlations in Fram Strait based on the MIZEX 84 data, Oceanologia, 44, 243-272, 2001.

Schlosser, P., Bauch, D., Fairbanks, R. G., and Bönisch, G.: Arctic river-runoff: mean residence time on the shelves and in the halocline, Deep-Sea Res., 41, 1054-1068, 1994.

Schlosser, P., Ekwurzel, B., Khatiwala, S., Newton, R., Maslowski, W., and Pfirman, S.: Tracer studies of the Arctic freshwater budget, in: Freshwater balance of the Arctic Ocean, edited by: Lewis, E. L., NATO, 2000.

Schlosser, P., Newton, R., Ekwurzel, B., Khatiwala, S., Mortlock, R., and Fairbanks, R.: Decrease of river runoff in the upper waters of the Eurasian Basin, Arctic Ocean, between 1991 and 1996: evidence from $\delta_{18} \mathrm{O}$ data, Geophys. Res. Lett., 29, 1289, doi:10.1029/2001GL013135, 2002.

Serreze, M. C., Barrett, a. P., Slater, A. G., Woodgate, R., Aagaard, K., Lammers, R. B., Steele, M., Moritz, R., Meredith, M., and Less, C. M.: The large-scale freshwater cycle of the Arctic, J. Geophys. Res., 111, C11010, doi:10.1029/2005JC003424, 2006.
Steele, M., Morison, J., Ermold, W., Rigor, I., Ortmeyer, M., and Shimada, K.: Circulation of summer Pacific halocline water in the Arctic Ocean, J. Geophys. Res., 109, C02027, doi: doi10.1029/2003JC002009, 2004.

Taylor, J. R., Falkner, K. K., Schauer, U., and Meredith, M.: Quantitative considerations of dissolved barium as a tracer in the Arctic Ocean, J. Geophys. Res., 108, 3374, doi:10.1029/ 2002JC001635, 2003.

Yamamoto-Kawai, M., McLaughlin, F. A., Carmack, E. C., Nishino, S., and Shimada, K.: Freshwater budget of the Canada Basin, Arctic Ocean, from salinity, $\delta_{18} O$, and nutrients, J. Geophys. Res., 113, C01007, doi:10.1029/2006JC003858, 2008. 